\title{
Relationship between Incentives and Organizational Performance for Employees in the Jordanian Universities
}

\author{
Marwan Al-Nsour (Associate professor) \\ Faculty of Planning and Management, Al-Balqa' Applied University \\ Assalt, Jordan \\ E-mail: marwan_alnsour@yahoo.com
}

Received: June 21, 2011

doi:10.5539/ijbm.v7n1p78
Accepted: September 9, 2011

Published: January 1, 2012

URL: http://dx.doi.org/10.5539/ijbm.v7n1p78

\begin{abstract}
The purpose of this study is to investigate the impact of financial and moral incentives on organizational performance for the employees of the Jordanian Universities. This study aims at identifying the role of the Jordanian universities in meeting the employees' societal needs, knowing the implemented incentives approach and knowing the level of performance in the Jordanian universities.

Statistical packages for social sciences (SPSS) program was used for descriptive analysis. Five universities were selected for the purpose of this study.

The main findings indicate that there is an adequate level of incentives provided to employees. Financial incentives ranked in 1st place while moral incentives ranked in the 2nd place.

Also, it was found that there is a high level of organizational performance. Customer satisfaction ranked in the 1st place, internal business process in the 2nd place followed by learning and growth. There is relationship between financial \& moral incentives and organizational performance as well as between financial \& moral incentives and internal business process and customer satisfaction.

There is an effect of moral incentives on learning \& growth but there is no relationship between financial incentives and learning \& growth.

Finally, this study has verified further research opportunities that could enrich the understanding of Incentives and organizational Performance in the universities of Jordan.

Keywords: Incentives, Organizational performance, Education, Universities, Jordan

\section{Introduction}

Business organizations are facing significant challenges on internal and external work environment, so organizations can not maintain institutional performance without providing incentives to their employees based on their efficient and effective work

Jordanian universities, like other universities, are facing many challenges under globalization, especially in terms of providing incentives to employees, so these universities need to formulate an integrated system of incentives commensurate with the developments of work to serve general objectives of increasing productivity, cost reduction, provide high quality services, achieve competitive share in the market and customer satisfaction.
\end{abstract}

\subsection{Study Problem}

The problem of the study is to what extent Jordanian universities implementing just incentive approach. Therefore, the researcher will answer the following questions:

What is the level of incentives provided to employees in the Jordanian Universities?

What is the level of organizational performance in the Jordanian universities?

\subsection{Study Objectives}

This study aims to: 
- Identify the reality and the role of the Jordanian universities in meeting societal needs of the employees.

- To know the implemented incentives approach in the Jordanian universities.

- To identify financial and moral incentives adopted in the Jordanian universities.

- To know the level of organizational performance in the Jordanian universities

\subsection{Study Importance}

The importance of this study includes the following:

- The universities role in society, which means the need for an ambitious incentive approach.

- The existence of the financial and moral incentives approach in Jordanian universities contribute to improve organizational performance.

\section{Theoretical framework}

Incentives are designed to encourage performance of individual's regardless of incentives' forms. Incentives play an active role in pushing forward individual's capacity and moving abilities, motivating them to develop their skills, and balance between organization requirements and the individuals' needs which enhance the organization performance efficiently and effectively.

\subsection{The Concept of Financial incentives}

Financial incentives mean the amounts paid to employees, either in the form of a lump sum or in the form of monthly payments including all additional income for the individual. They are considered the oldest forms of incentives which characterized by quick and immediate form that make individuals feel of an immediate feed back of their effort.

As defined by Lawzi (1995) financial incentives are set to satisfy basic human needs, encouraging workers to do their best of work performance, the recruitment of their capabilities and increase the level of their competences such as salary, bonuses, allowances, profit sharing and rewards.

Financial incentives also defined by Jadallah (1997) as all means of payment based on increase and or improve productivity. Therefore the more the workers produce the more they earn. While the fall in quantitative or qualitative production deprive the worker from earning partial or total incentives.

Financial incentives aim to raise production efficiency and improve performance through encouraging individual to behave in a desired away. Financial incentives are the most important and influential factors to the individual's desire to work when such wages are appropriate and capable of satisfying his needs. On the contrary, low payment that is not appropriate to his efforts of work leads to the low efficiency of productivity (Al-Harthi, 1999).

The advantages of financial incentives as follows:

There is a rapid and immediate impact on the individual's efforts that motivate him in doing his utmost of work, increase production, increase income and improve performance.

The individual gains several psychological and social benefits as a result of enhancing his purchasing power to satisfy his needs of goods and services (Al-Jahni, 1998).

The disadvantages of financial incentives could push the individual for hard work, often affecting the workers' physical or mental condition in the future and affect his social and humanitarian issues which do not take into consideration the individual's s age or his circumstances.

Financial incentives could not be valid for a number of work activities that are not based on quantity of production but rather on services such as business services, supervision, security, the judiciary and scientific research (Angari, 1999).

Financial incentives alone are not sufficient unless assisted by other types of incentives. Their effects are limited to satisfy the biological needs of individuals and have a little impact after it reaches the limit of needs. Therefore individuals are not seeking to increase production for additional financial gains, thus can not be financially motivated to contribute in increasing production except for a certain amount based on their efforts (Aldubekhi, 1991).

There is a direct relationship between increased production and the interest of the worker, so financial incentives is an essential factor to the individual, in addition to stability and reassurance and gives him the opportunity to explore their talents and expertise (Jadallah, 1997). 


\subsection{The Concept of Moral Incentives}

"A person has a moral incentive to behave in a particular way when he has been taught to believe that it is the right or proper or admirable thing to do. If he behaves as others expect him to, he may expect the approval or even the admiration of the other members of the collectivity and enjoy an enhanced sense of acceptance or self-esteem. If he behaves improperly, he may expect verbal expressions of condemnation, scorn, ridicule or even ostracism from the collectivity, and he may experience unpleasant feelings of guilt, shame or self-condemnation" (Johnson, 2005, p, 1).

Moral incentives are those related to aspects of psychological needs, the increased attention to this aspect came after the emergence of human relations theories. Moral incentives are based on respect of a human being who has feelings, hopes and aspirations (Akaili, 1996).

Moral incentives could be in the form of participate in decision-making, certificates of thanks and appreciation, training and parties for distinguished employees.

Also, moral incentives could be in other forms such as; sending the employee a letter of thanks or choosing him as honor employee in the organization (Assaf, 1999). lawzi (1995) said that increasing individual's satisfaction and loyalty to his work, enhance more cooperation with his colleagues that include the chance for promotion, recognition and appreciation of job efforts, responsibilities of the post, impact of the career, participation in decision-making, opportunities for growth and innovation and the chance to express his opinion .

Al-Harthi (1999) suggests that moral incentives are not less important than financial incentives. So, financial incentives cannot be achieved unless accompanied by moral incentives. The importance of moral incentives depends on the conditions of the Organization, thus, it can choose between financial incentives that fit the organization's circumstances and moral incentives that are necessary to satisfy the social needs of the individual.

Moral incentives are those related to work environment such as; supervision, leadership, fellowship, the working conditions of light, heat, ventilation, noise, decorations and participation in management (Hasan, 2002).

Al-Jahni (1998) defines moral incentive as a set of motives aimed at achieving emotional, psychological and humanitarian needs for employees by treating them properly and eliminate the causes of complains, reward and punishment rule, provide systemic and entertainment services for employees, and raise spiritual enhancement .

It can be concluded that positive moral incentives are any consequent raise of spirit for the individuals, such as job enrichment, holidays, the appropriate post, participation in decision-making, promotion, the nature of supervision, sense of belonging, stability, security, confidence in the objectives of the Organization, systems proposals, listing in the panel of honor, social harmony, literarily and moral distinguishing. Negative moral incentives are for negligent acts, such as blame and shame.

\subsection{Theories of incentives}

Theory of behavior change is interested in motivation of external behavior more than interior behavior, for example, fear is an interior sense of danger while scholars consider it as a natural phenomenon in many forms such as Running, dry throat and trembling knees." Behavior change is often a goal for staff working directly with constituents, organizations, governments, or communities. Individuals charged with this task can be thought of as "interventionists" whose goal it is to design and implement programs or interventions that produce the desired behavioral changes" (Glanz, Lewis, \& Rimers, 1990, p. 17). It means any change of human behavior through the use of positive or negative support elements. This applies to both the organization and the individual. So when the individual in the organization perform well, the management should praise him in any form of incentives. (Judeh, 1985).

One of McClelland's most well known theories is that human motivation. McClelland developed a meaning for motivation and a model of motivation. He stated that intrinsic motivators are critical to meeting a person's needs, because they describe a pattern of how an individual may behave. McClelland's theory of motivation dominated by three types of motivational needs: The need for achievement, the need for affiliation and the need for power. People have either one of these needs or a combination of these three needs which motivate them toward a certain pattern of behavior (McClelland, 1962).

-The need for affiliation: This is the need for friendly relationships and human interaction. There is a need "to feel liked" and "accepted" by others.

- The need for power: This is the need to lead others and make an impact. This need can exhibit itself in two ways. The first which is the need for personal power may be viewed as undesirable as the person simply needs to feel that they have "power over others". The second type of "need for power" is the need for institutional power. 
People with the need for institutional power; want to direct the efforts of their team, to further the objectives of their organization.

- The need for achievement: This is the need to achieve, excel and succeed. A person with this type of need will set goals that are challenging but realistic. The goals have to be challenging so that the person can feel a sense of achievement. However the goals also have to be realistic as the person believes that when a goal is unrealistic, its achievement is dependant on chance rather than personal skill or contribution. This type of person prefers to work alone or with other high achievers.

Atkinson and Feather (1966) determine a person's achievement orientation toward a specific task into two separate motives: to achieve success, and to avoid failure. The motive to achieve success is determined by three things: the need to succeed or need achievement; the person's estimate of the likelihood of success in performing the particular task; and the incentive for success-that is, how much the person wants to succeed in that particular task

The motive to avoid failure is determined by three similar considerations: the need to avoid failure which, like the need to achieve success, varies among individuals; the person's estimate of the likelihood of failure at the particular task; and (3) the incentive value of failure at that task, that is, how unpleasant it would be to fail. The relative sire of the motives to succeed and to avoid failure determines the level of task difficulty people will prefer (Atkinson \& Birch 1970).

Alderfer (1969) who further expanded Maslow's hierarchy of needs by categorizing the hierarchy into his ERG theory (Existence, Relatedness and Growth). Alderfer categorized the lower order needs (Physiological and Safety) into the Existence category. He fit Maslow's interpersonal love and esteems needs into the Relatedness category. The Growth category contained the self actualization and self esteem needs.

He also proposed a regression theory to go along with the ERG theory. He said that when needs in a higher category are not met then individuals redouble the efforts invested in a lower category need. For example if self actualization or self esteem is not met then individuals will invest more effort in the relatedness category in the hopes of achieving the higher need.

Maslow's hierarchy of needs (1954) is a theory in psychology, proposed by Abraham Maslow in his 1943 paper A Theory of Human Motivation. Maslow subsequently extended the idea to include his observations of humans' innate curiosity. His theories parallel many other theories of human developmental psychology, all of which focus on describing the stages of growth in humans. (Salem, Ramadan \& Darhan, 2000).

Ahmad (2000) explains the Theory of expected value and identifies two key requirements for Individual's motivation of achievement; predicting a successful mission and its collection value. This will develop the individual's self-efficiency to achieve a goal and seek to deal with more complex problems previously dealt with it.

Individual's satisfaction can not be achieved as a result of reaching a goal, but rather is the result of the individual's awareness of his effort in achieving this goal. So that the individual achieves positive sense of confidence and satisfaction when he accepts the expected result in return for his effort (Ayasrah, 2006).

Organization's performance can be measured by comparing actual results with those estimated for each program and strategy, in addition to identify positive and negative deviations. These standards should reflect the goals of the organization, which determines the organization's direction to enable it to take appropriate corrective action. standards, however are differ from one organization to another, but they have common ones that cover all areas of performance such as standards of profitability, market share, productivity, human resource development, leadership and employees behavior, social responsibility, the balance between the long and short- run goals (Gattas, 1998).

Wheelen and Hunger (2002, p. 243) defined performance simply as "the end result of activity." At one level, it may be as simple and mundane as this definition, although at another level the notion of a general measure of performance is both intriguing yet continually disappointing (Bonoma \& Clark 1988).

Adlouni (2002) believes that organization's performance indicators include customer satisfaction, employees' satisfaction, market share, gains and results, overall performance and leadership support.

\section{Literature review}

There are several studies related to this paper. The most important of these studies are as follows:

Bailey, Brown \& Cocco (1998) examine the impact of piece-rate and goal-contingent incentives, versus fixed-pay, on initial performance and subsequent improvement rate in an assembly task. They found that both 
overall and initial performance, but not improvement rate, are higher in the incentive-pay groups. Two factors may explain the lack of differential improvement rates: subjects? Effort allocation, since improving initial performance may be easier than improving subsequent performance; and the nature of these typical incentive-pay plans, which do not reward improvement directly.

Al-Harthi (1999) investigates the relationship of financial and moral incentives to raise the efficiency of employees in the Department of Civil Defense in Riyadh, Saudi Arabia. He found that financial and moral incentives are unsatisfactory and may lead to a decrease in the level of performance of employees. Promotion is the most important incentives affecting the efficiency of the employees' performance, while financial incentives ranked first in importance to raise the efficiency of the performance of employees, followed by moral incentives.

Angari (1999) conducted a field study on incentive and its role in raising the level of employee performance in Riyadh, Saudi Arabia.

The results showed that there was no satisfaction for financial and moral incentives. The financial incentives ranked first among other incentives. The most important problem faced by the employees is the lack of a clear independent and promotion incentive rules in the civil service.

Al-Aydi (2000) investigates the effect of incentives on the level of performance in the textile industry in Iraq. He found out that there is a weak relationship between the incentives system and the level of performance and between the wages system and the level of performance. Also there is a strong correlation between rewards and the level of financial performance, appropriate promotion system and level of performance.

Alwabel (2005) investigates the role of financial and moral incentives in raising the performance level of employees from the viewpoint of public security officers participating in the Hajj season. The results showed that there are no incentives standards provided to the officers but the degree of their satisfaction is very high and incentives play a major role in raising the level of performance.

A Study of Individual Incentives versus Team Performance: Lessons from a Game of Charades (Shawn, Patricia \& Marlon 2007) describe a modified game of Charades that was developed to facilitate a discussion on the basic principles of effective reward system design. Students are organized into small groups. Incentive schemes are then manipulated so that one player within the group strives for an individual incentive, while the rest of the team play for a group reward. Through this simple and "fun" activity, students learn firsthand what happens when individual and team interests and incentives are not aligned. This experiential learning activity also offers excellent opportunities to discuss group dynamics, communication and coordination, and the importance of maintaining a systemic view of organizational performance

Abang, A., May-Chiun, \& Maw (2009) found that firm performance has important implications for employees and organizations by examining human resource practices and the impact of incentives on manufacturing companies in the Malaysia context. The results have indicated that the two components of human resource practices namely, training and information technology have direct impact on organizational performance. It was found that incentive is positively related to organizational performance but did not moderate the relationship between both HR practices and organizational performance.

Koonmee (2010) discusses Development of Organizational Justice in Incentive Allocation of the Thai Public Sector by comparing the roles of distributive and procedural justice on national personnel's attitudinal outcomes (incentive satisfaction and job performance). He found that distributive justice and procedural justice played more important roles in predicting incentive satisfaction and job performance in 2008 than in 2006.

In Schmidt (2010) paper, are Incentives the Bricks or the Building? The efforts of economists to emphasize the importance of incentives as determinants of organizational performance, while successful to some degree, may have left the mistaken impression that "getting the incentives right" is the only task requiring the attention of senior executives when designing corporate organizations. The author identifies the incentive-intensive companies envisioned by economists as "mercenary organizations", or companies whose distinguishing feature is near-complete reliance on financial rewards and controls. Citing the difficulties of devising an effective incentive system that cannot be gamed (which he calls the organizational equivalent of "an anti-gravity machine"), the article questions whether such organizations are likely to yield superior performance.

\section{Hypotheses}

Based on the study aim and objectives, the following hypotheses can be formulated:

Main hypothesis

H0: There is no significant relationship between financial \& moral incentives and organizational performance in 
the Jordanian universities.

Sub-hypotheses:

H01: There is no significant relationship between financial \& moral incentives and learning \& growth in the Jordanian universities.

H02: There is no significant relationship between financial \& moral incentives and internal business process in the Jordanian universities.

H03: There is no significant relationship between financial \& moral incentives and customer satisfaction in the Jordanian universities.

\section{Methodology}

\subsection{Sampling}

Five universities from (24) universities have been selected: Amman Private University, Al-Balqa Applied University, Philadelphia University, Jerash university and Amman Arab University located in Balqa Governorate. The sample consists of 500 persons. 421 questionnaires were returned, and (32) were excluded.

\subsection{Instrument}

A five point likert scale was used with weighed Mean of 3.00 and above as the criteria cut off point for the level of agreement.

The study instrument was based on the theoretical literature of the incentives concept and organizational performance in addition to a number of questionnaires used in previous studies.

The first part of the questionnaire devoted to gather personal and professional data for Jordanian universities employees that includes social status, qualifications and experience.

The second part of the questionnaire was devoted to measure the independent and dependent variables.

The questionnaire consists of 32 paragraphs of which paragraphs (1-16) measure the independent variable (incentives). Paragraphs (1-7) measure the financial incentives and paragraphs (8-16) measure the moral incentives. paragraphs (17-32) measure the dependent variable (organizational performance) of which paragraphs (17-21) measure the learning and growth, and paragraphs (22-27) measure the internal business process and paragraphs (23-32) measure the customer satisfaction .

\subsubsection{Validity}

The questionnaire was reviewed by management professors to verify the validity of the paragraphs and I have rewritten paragraphs $(13.15,21)$ in accordance to their notes.

\subsubsection{Reliability}

Cronbach's $\alpha$ (alpha) as a coefficient of reliability was used to measure the internal consistency for all variables. $\alpha$ for financial incentives 0.76 , moral incentives 0.79 , organizational performance for learning and growth 0.82 , internal business process 0.87 and customer satisfaction 0.81 . Coefficient ranged between $(0.76-0.82)$ which indicates the reliability of the study.

\section{Analytical procedure}

Statistical packages for social sciences (SPSS) program was used to for descriptive analysis to the study questions and test hypotheses as follows: - Frequencies and percentages to identify the characteristics of the study sample. - Arithmetic means and standard deviations for the analysis of the questionnaire paragraphs and arrange them according to their relative importance inorder to answer the study questions.

- Multiple regressions to test hypotheses of the study.

\section{Findings}

\subsection{Descriptive Analysis}

To answer the first question which states that "what is the level of incentives provided to employees in the Jordanian universities?" Results from table (1) shows that the level of incentives provided to employees in Jordanian universities is acceptable where the mean score is (3.55), standard deviation (0.67). The financial incentives level ranked first with mean score of (3.56), while the moral incentives ranked 2 nd with the mean score of (3.55).

To answer the second question which states that "what is the level of organizational performance in the 
Jordanian universities?" Results emanated from table (2) shows that the level of organizational performance in the Jordanian universities is high with mean of (3.67). Customer satisfaction ranked first with mean of (3.82) followed by internal business process with mean of (3.64), while the mean for learning and growth reached (3.56).

\subsection{Hypotheses Testing}

H0: There is no significant relationship between financial \& moral incentives and organizational performance in the Jordanian universities.

Table (3) shows that calculated $\mathrm{f}$ (163.248) with (0.00) significance is less than (0.05), $(\alpha \leq 0.05)$. Providing incentives explains $(45.8 \%)$ of the variance in the organizational performance which indicates financial and moral incentives significance on organizational performance.

Calculated $(t)$ values for financial and moral incentives are (2.921 and 10.177) respectively with $(t)$ significance values of $(0.004,0.000)$ respectively which less than the level of significance $(0.05)$. Thus, enhanced the high coefficients of (Beta) with values of $(0.159,0.553)$ respectively.

Based on these results we reject the null hypothesis and accept the alternative hypothesis which states that "There is significant relationship between financial \& moral incentives and organizational performance in the Jordanian universities".

H01: There is no significant relationship between financial \& moral incentives and learning \& growth in the Jordanian universities.

Results obtained from table (4) shows that the value of the calculated (f) is equal to (71.281). The value of $f$ significance $(0.00)$ is less than the level of significance 0.05 . Providing financial and moral incentives explains $(27 \%)$ of the variance in learning and growth which indicates the incentives significant effect on learning and growth.

While moral incentives have an impact on learning and growth as the value of calculated $(t)$ reached (8.152) with significance value of $(0.000)$ which is less than the significance level $(0.05)$. This enhanced the high coefficient of Beta (0.514). It is further noted that financial incentives have no effect on learning and growth as the value of calculated $(t)$ reached $(0.108)$ with significance value of $(0.914)$ which is greater than $(0.05)$. Coefficient of Beta (0.007) is low.

We can conclude that we can reject the null hypothesis and accept the alternative hypothesis of the moral incentives which states that "There is significant relationship between moral incentives and learning \& growth in the Jordanian universities" and reject the alternative hypothesis and accept the null hypothesis which states that "There is no significant relationship between financial incentives and learning \& growth in the Jordanian universities".

H02: There is no significant relationship between financial \& moral incentives and internal business process in the Jordanian universities.

Table (5) shows the value of calculated (f) reached (104.262) with significance value of (0.00) which is less than (0.05). Providing incentives explains (35.1\%) of the variance in internal business process which indicates the presence of significant effect of providing incentives on internal business process.

The calculated $(\mathrm{t})$ values for financial and moral incentives are (2.625 and 7.888) respectively with ( $\mathrm{t})$ significance values of $(0.009,0.000)$ respectively are less than the $(0.05)$. Thus, enhanced the high coefficients of (Beta) with values of $(0.156,0.469)$.

We can conclude to reject the null hypothesis and accept the alternative hypothesis which states that "There is significant relationship between financial \& moral incentives and internal business process in the Jordanian universities".

H03: There is no significant relationship between financial \& moral incentives and customer satisfaction in the Jordanian universities.

Table (6) shows the validity of the hypothesis as the value of calculated (f) is $(92.362)$ with significance of $(0.00)$ which is less than (0.05). Providing incentives explains (32.4\%) of the variance in public satisfaction which indicates there is significant effect of providing incentives on customer satisfaction.

Financial and moral incentives have an impact on customer satisfaction. The values of calculated ( $t)$ are (4.139, $5.927)$ respectively with the significance values of $(0.000)$ which is less than $(0.05)$. Thus, enhanced the high coefficients of Beta $(0.251,0.360)$ respectively. 
Based on these results, we can conclude that we can reject the null hypothesis and accept the alternative hypothesis which states that "There is significant relationship between financial \& moral incentives and customer satisfaction in the Jordanian universities".

\section{Conclusions}

The study reached the following conclusions:

-The level of incentives provided to employees in the Jordanian universities is adequate. Financial incentives ranked in 1st place while moral incentives ranked in the 2 nd place.

- There is a high level of organizational performance in the Jordanian universities. Customer satisfaction ranked in the 1st place, internal business process in the 2nd place followed by learning and growth.

- There is significant relationship between financial \& moral incentives and organizational performance in the Jordanian universities.

- There is significant relationship between moral incentives and learning \& growth in the Jordanian universities and there is no relationship between financial incentives and learning \& growth in the Jordanian universities.

- There is significant relationship between financial incentives \& moral incentives and internal business process in the Jordanian universities

- There is significant relationship between financial \& moral incentives and customer satisfaction in the Jordanian universities.

\section{Limitations}

This study is subject to a limitation and might be explored in future research. Five universities were selected. Results could vary from one study to another one that depends on the incentive approach adopted by these universities. Despite this limitation, this study has provided several important insights into issues relating to incentives. Hopefully, this study will encourage other researchers to conduct further studies in this field such as:

- The impact of financial and moral incentives on raising the level of employees ' performance in the Jordanian universities.

- The relation between motivation achievement and the level of meeting the employees' basic needs in private educational institutions.

- A comparative study between the level of financial and moral incentives provided to employees in public and private Jordanian universities.

- Evaluating the performance of employees in the Jordanian universities from the viewpoint of students.

\section{References}

Abang, A., May-Chiun, L., \& Maw King, L. (2009). Human Resource Practices and Organizational Performance. Incentives as Moderator. Journal of Academic Research in Economics, 1 (2), 219-234.

Adlouni, M. (2002). Organizational work. Amman: Dar Iben Hazem

Ahmad, N. (2000). Factors Affecting the Development of Motivation Among students in Primary Schools in the Governorate of Amman. Master Thesis. University of Jordan. [Online] Available: http://www.ju.edu.jo/sites/Academic/mbatsh/Lists/ThesesDissertationsSupervision/AllItems.aspx (May 2, 2010).

Akaili, O. (1996). Workforce Management. Amman: Dar Zahran.

Al -Jahni, A. (1998). Evaluation of Incentive System in the General Directorate of Passports from the Perspective of Workers: Case Study on Jeddah Passports Department. Master Thesis. Naif Arab Academy for Security Sciences. Riyadh, Saudi Arabia.

Al-Aydi, K. (2000). Impact of Incentives on Performance in Public Firms of Cotton Industry in Iraq: a field Study. Master Thesis. Al al-Bayt University, Mafraq, Jordan. [Online] Available: http://web2.aabu.edu.jo/thesis_site/thes_dtl.jsp?thes_no=1811 (July 7, 2010).

Alderfer, C. P. (1969). An Empirical Test of a New Theory of Human Needs. Organizational Behavior and Human Performance, 4 (2), 142-175. http://dx.doi.org/10.1016/0030-5073(69)90004-X

Aldubekhi, I. (1991). Incentives and Rewards Assessment in the Saudi Customs as A mean to Curb Smuggling. Riyadh: Institute of Public Administration.

Al-Harthi, D. (1999). Raising the Efficiency of Workers and Relationship with Financial and Moral Incentives: 
Case study on the Civil Defense Personnel in Riyadh. Master Thesis. Naif Arab Academy for Security Sciences. Riyadh, Saudi Arabia.

Alwabel. A. (2005). The Role of Financial and Moral Incentives on Raising the Performance Level of Employees from the Viewpoint of the Security Officers Involved in the Pilgrimage Season. Master Thesis. Naif Arab University for Security Sciences. Riyadh, Saudi Arabia. [Online] Available: http://www.seminar.ps/library/cat:106:\&selectedPage=20 . (Aug 13, 2009).

Angari, A. (1999). Incentive systems and their role in raising the level of performance of employees: case study on workers in the Emirate of Riyadh Region. Master Thesis. Naif Arab Academy for Security Sciences. Riyadh, Saudi Arabia.

Assaf, A. (1999). Managerial Behavior in Contemporary Organizations. Amman: Dar Zahran.

Atkinson, J. W., \& Birch, D. (1970). The Dynamics of Action. New York, N.Y.: John Wiley.

Atkinson, J. W., \& Feather, N. T. (1966). A theory of Achievement Motivation. New York: Wiley.

Ayasrah, A. (2006). Leadership and motivation in educational administration. (1st Ed.). Amman: Dar AL-Hamid for printing and distribution.

Bailey, C. D., Brown, L. D., \& Cocco, A. F. (1998). The Effects of Monetary Incentives on Worker Learning and Performance in an Assembly Task. Journal of Management Accounting Research, 10, 119-131.

Bonoma, T.V., \& Clark, B.H. (1988). Marketing Performance assessment. Boston: Harvard Business School Press.

Gattas, N. (1998). Practical Guide to Prepare and Implement Strategic Plan for the Organization. Nicosia: Gattas and Partners.

Glanz, K., Lewis, F. M., \& Rimers, B. K. (1990). Health Behavior and Health Education: Theory, Research, and Practice. San Francisco, CA: Jossey-Bass.

Hasan, R. (2002). Behavior of the Organizations. Alexandria: Aldar Aljamyiah.

Jaber, A. (1991). Professional Trends' Relationship with Performance of Social Workers in Public Hospitals in the Western Region. Master Thesis. University of Umm Al-Qura. Mecca, Saudi Arabia.

Jadallah, M. (1997). The Impact of Incentives in Raising the Efficiency of Workers. Management Development, $56(51), 34-46$.

Johnson, P. M. (2005). A Glossary of Political Economy Terms. [Online] Available: http://www.auburn.edu/ johnspm/gloss/incentive. (Jan 27, 2010).

Judeh, A. (1985). Incentives. Damascus: The Arab Organization for Administrative Sciences.

Koonmee, K. (2010). Development of Organizational Justice in Incentive. World Academy of Science, Engineering and Technology, (66), 861-867.

Lawzi, M. (1995). Individuals' Attitudes Working in Public Institutions in Jordan towards Job Incentives. Derasat, Humanities Studies, 22a (6), 759-785.

Maslow, A. (1954). Motivation and Personality. New York: Harper.

McClelland, D. C. (1962). The Achieving Society. NJ: Van Nostrand Press.

Salem, F., Ramadan, Z., \& Darhan, O. (2000). Concepts of modern management, (6th Ed.). Amman: Jordan Book Center.

Schmidt, R. (2010). Are Incentives the Bricks or the Building? Journal of Applied Corporate Finance, 22 (1), 129-136. http://dx.doi.org/10.1111/j.1745-6622.2010.00268.x

Shawn, E. P., Patricia, D. L., \& Marlon, F. S. (2007). Individual Incentives versus Team Performance: Lessons from a Game of Charades. Organization Management Journal, (4), 54-68. http://dx.doi.org/10.1057/omj.2007.7

Wheelen, T. L., \& Hunger, D. J. (2002). Strategic Management and Business Policy. (8th Ed.). New Jersey: Prentice Hall. 
Table 1. The level of Incentives Provided to Workers in the Jordanian Universities

\begin{tabular}{|l|c|c|c|c|}
\hline Incentives & Mean & $\begin{array}{c}\text { Standard } \\
\text { Deviation(SD) }\end{array}$ & Rank & Level \\
\hline financial & 3.56 & 0.80 & 1 & Adequate \\
\hline moral & 3.55 & 0.66 & 2 & Adequate \\
\hline Overall & 3.55 & 0.67 & - & Adequate \\
\hline
\end{tabular}

Table 2. The level of organizational Performance in the Jordanian Universities

\begin{tabular}{|l|c|c|c|c|}
\hline $\begin{array}{l}\text { organizational } \\
\text { Performance }\end{array}$ & Mean & $\begin{array}{c}\text { Standard } \\
\text { Deviation(SD) }\end{array}$ & Rank & $\begin{array}{c}\text { Performance } \\
\text { level }\end{array}$ \\
\hline Customer satisfaction & 3.82 & 0.63 & 1 & High \\
\hline Internal business process & 3.64 & 0.63 & 2 & Medium \\
\hline Learning and Growth & 3.56 & 0.78 & 3 & Medium \\
\hline Overall & 3.67 & 0.56 & - & Medium \\
\hline
\end{tabular}

Table 3. Impact of Incentives on organizational Performance

\begin{tabular}{|l|c|c|c|c|c|c|}
\hline $\begin{array}{l}\text { Independent } \\
\text { variables }\end{array}$ & Beta & $\begin{array}{c}\text { T Value } \\
\text { calculated }\end{array}$ & $\begin{array}{c}\mathrm{T} \\
\text { significance } \\
\text { Level }\end{array}$ & $\begin{array}{c}\text { F value } \\
\text { calculated }\end{array}$ & $\begin{array}{c}\mathrm{F} \\
\text { significance }\end{array}$ & $\mathrm{R} 2$ \\
\cline { 1 - 1 } $\begin{array}{l}\text { Financial } \\
\text { incentives }\end{array}$ & 0.159 & 2.921 & $0.004^{*}$ & 163.248 & $0.00^{*}$ & 0.458 \\
\cline { 1 - 4 } $\begin{array}{l}\text { Moral } \\
\text { incentives }\end{array}$ & 0.553 & 10.177 & $0.00^{*}$ & & & \\
\hline
\end{tabular}

Table 4. The Impact of Incentives on Learning and Growth

\begin{tabular}{|l|c|c|c|c|c|c|}
\hline $\begin{array}{l}\text { Independent } \\
\text { variables }\end{array}$ & Beta & $\begin{array}{c}\text { T Value } \\
\text { calculated }\end{array}$ & $\begin{array}{c}\mathrm{T} \\
\text { significance } \\
\text { Level }\end{array}$ & $\begin{array}{c}\text { F value } \\
\text { calculated }\end{array}$ & $\begin{array}{c}\mathrm{F} \\
\text { significance }\end{array}$ & $\mathrm{R} 2$ \\
\hline $\begin{array}{l}\text { Financial } \\
\text { incentives }\end{array}$ & 0.007 & 0.108 & 0.914 & 71.281 & $0.00^{*}$ & 0.270 \\
\cline { 1 - 4 } $\begin{array}{l}\text { Moral } \\
\text { incentives }\end{array}$ & 0.514 & 8.152 & $0.00^{*}$ & & & \\
\hline
\end{tabular}

Table 5. The Impact of Incentives on internal business process

\begin{tabular}{|l|c|c|c|c|c|c|}
\hline $\begin{array}{l}\text { Independent } \\
\text { variables }\end{array}$ & Beta & $\begin{array}{c}\text { T Value } \\
\text { calculated }\end{array}$ & $\begin{array}{c}\mathrm{T} \\
\text { significance } \\
\text { Level }\end{array}$ & $\begin{array}{c}\text { F value } \\
\text { calculated }\end{array}$ & F significance & R2 \\
\cline { 1 - 4 } $\begin{array}{l}\text { Financial } \\
\text { incentives }\end{array}$ & 0.156 & 2.625 & $0.009^{*}$ & 104.262 & $0.00^{*}$ & 0.351 \\
\cline { 1 - 4 } Moral incentives & 0.469 & 7.888 & $0.00^{*}$ & & & \\
\hline
\end{tabular}

Table 6. The Impact of Incentives on customer Satisfaction

\begin{tabular}{|l|l|c|c|c|c|c|}
\hline $\begin{array}{l}\text { Independent } \\
\text { variables }\end{array}$ & Beta & $\begin{array}{c}\text { T Value } \\
\text { calculated }\end{array}$ & $\begin{array}{c}\text { T } \\
\text { significance } \\
\text { Level }\end{array}$ & $\begin{array}{c}\text { F value } \\
\text { calculated }\end{array}$ & F significance & R2 \\
\cline { 1 - 4 } $\begin{array}{l}\text { Financial } \\
\text { incentives }\end{array}$ & 0.251 & 4.139 & $0.000^{*}$ & 92.362 & $0.00 *$ & 0.324 \\
\cline { 1 - 4 } Moral incentives & 0.360 & 5.927 & $0.000 *$ & & & \\
\hline
\end{tabular}


Questionnaire

\begin{tabular}{|l|c|c|c|}
\hline sex & Male & female & Graduate degree \\
\hline Qualification & $\begin{array}{c}\text { Below community college } \\
\text { diploma }\end{array}$ & $\begin{array}{c}\text { Under graduate } \\
\text { degree }\end{array}$ & More than 10 years \\
\hline Experience & Less than 5 years & $5-10$ years &
\end{tabular}

1st Financial incentives

\begin{tabular}{|l|l|l|l|l|l|l|}
\hline s/n & paragraph & Very high & high & adequate & low & Very low \\
\hline 1 & $\begin{array}{l}\text { The university provides enough payment } \\
\text { to meet the requirements of life. }\end{array}$ & & & & & \\
\hline 2 & $\begin{array}{l}\text { The university provides rewards for } \\
\text { skilled employees commensurate with } \\
\text { their performance. }\end{array}$ & & & & & \\
\hline 3 & $\begin{array}{l}\text { The university provides bonuses for } \\
\text { workers according to their post and } \\
\text { consistent with their level of performance. }\end{array}$ & & & & & \\
\hline $\mathbf{4}$ & $\begin{array}{l}\text { The university provides overtime payment } \\
\text { to employees after working hours. }\end{array}$ & & & & & \\
\hline 5 & $\begin{array}{l}\text { The university provides transportation } \\
\text { allowances for those who live in far areas. }\end{array}$ & & & & & \\
\hline 6 & $\begin{array}{l}\text { The university provides a fair and } \\
\text { adequate compensation on retirement. }\end{array}$ & & & & & \\
\hline 7 & $\begin{array}{l}\text { The university provides financial } \\
\text { incentives to employees when they work } \\
\text { professionally. }\end{array}$ & & & & & \\
\hline
\end{tabular}

2nd moral incentives

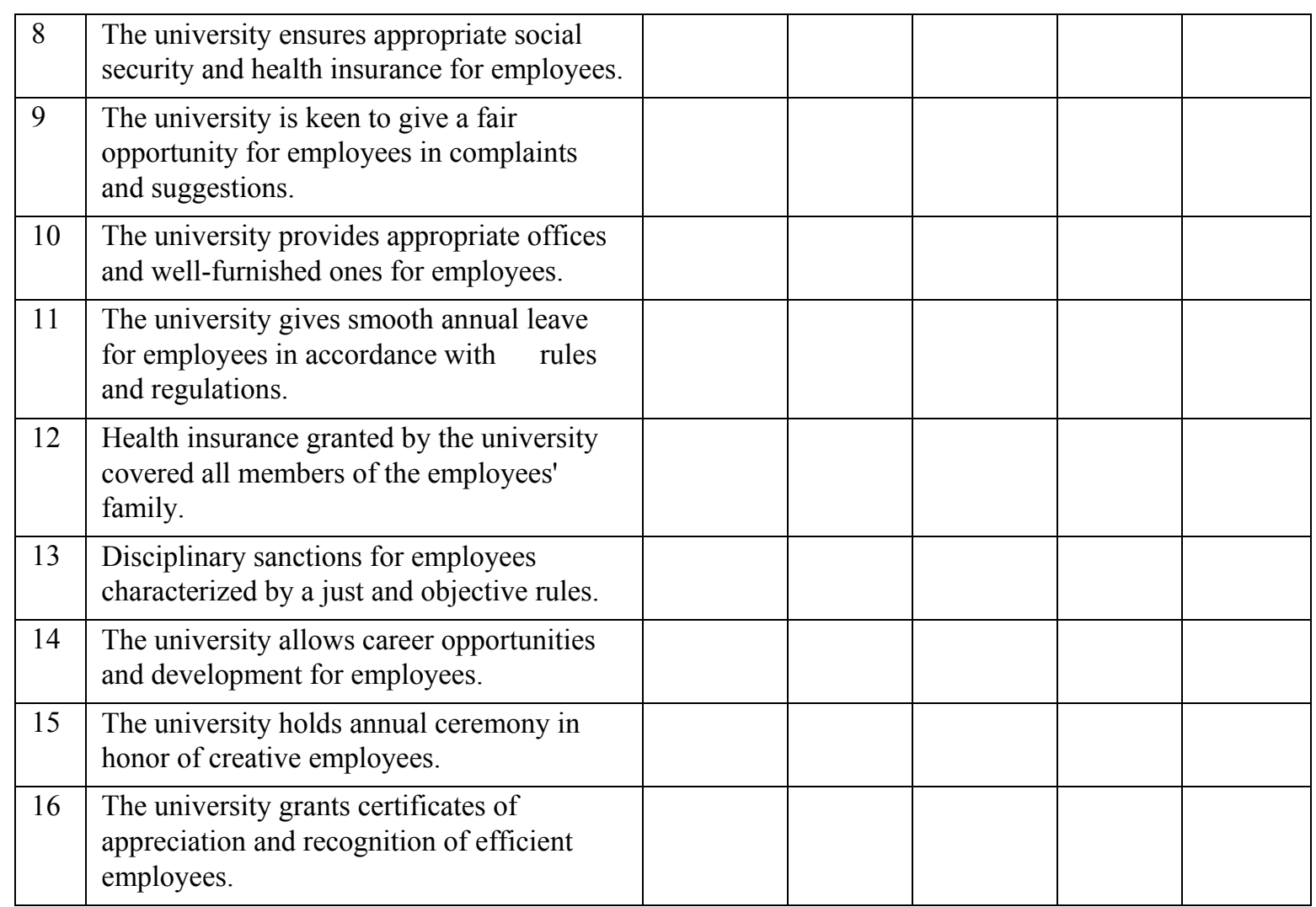


1- Learning and growth

\begin{tabular}{|l|l|l|l|l|l|l|}
\hline 17 & $\begin{array}{l}\text { The university place appropriate } \\
\text { methods to raise the level of learning } \\
\text { for employees. }\end{array}$ & & & & & \\
\hline 18 & $\begin{array}{l}\text { The University encourages academic } \\
\text { growth }\end{array}$ & & & & & \\
\hline 19 & $\begin{array}{l}\text { Employees are promoted when they } \\
\text { earn academic qualifications or } \\
\text { training }\end{array}$ & & & & & \\
\hline 20 & employees are trained continuously & & & & & \\
\hline 21 & $\begin{array}{l}\text { Sending employees for internal or } \\
\text { external training courses. }\end{array}$ & & & & & \\
\hline
\end{tabular}

2- Internal business process

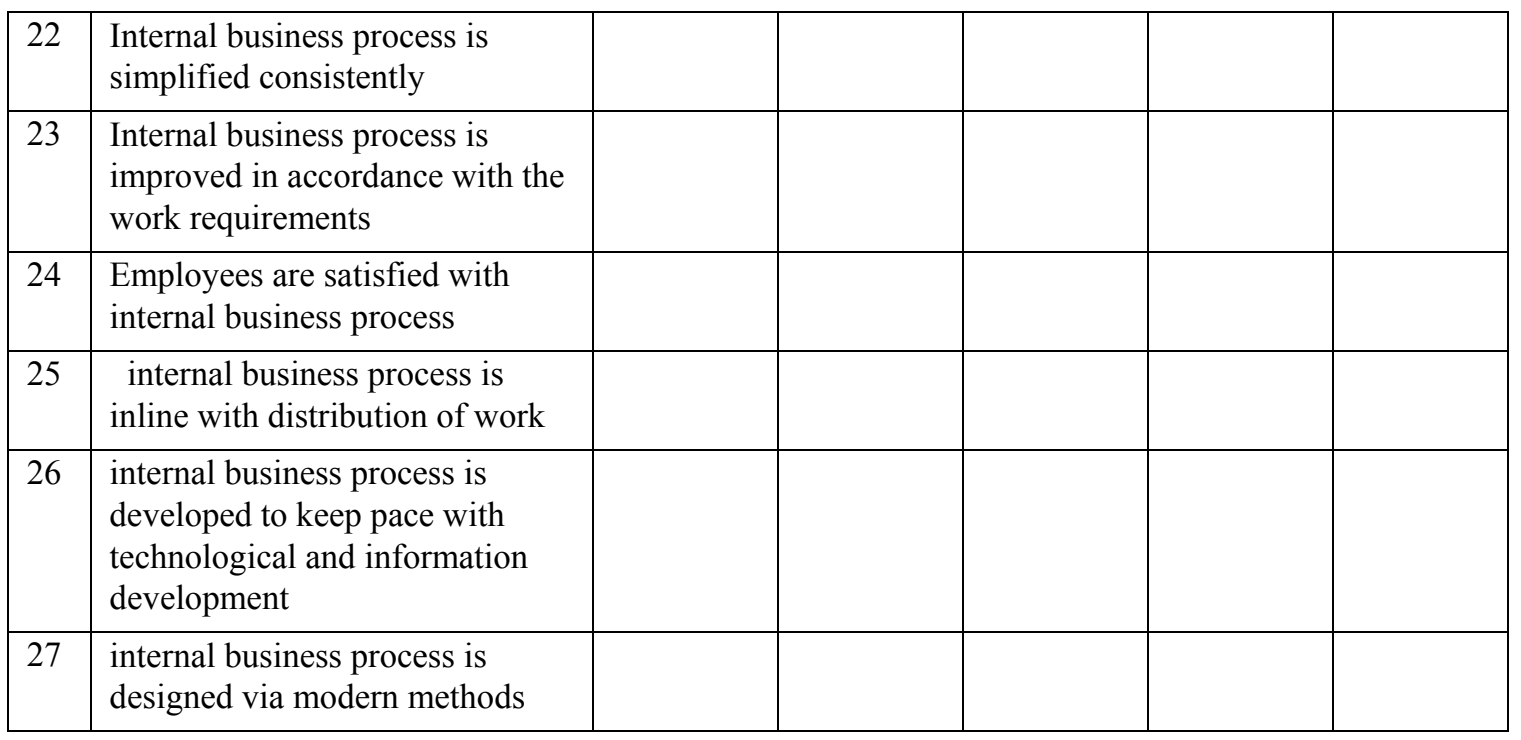

3- Customer satisfaction

\begin{tabular}{|c|l|l|l|l|l|l|}
\hline 28 & $\begin{array}{l}\text { Providing services achieved } \\
\text { student satisfaction }\end{array}$ & & & & & \\
\hline 29 & $\begin{array}{l}\text { Students complaint and } \\
\text { suggestions are taken into } \\
\text { consideration }\end{array}$ & & & & & \\
\hline 30 & $\begin{array}{l}\text { The university interested in } \\
\text { contacting the customer } \\
\text { constantly }\end{array}$ & & & & & \\
\hline 31 & $\begin{array}{l}\text { The University seeks to meet } \\
\text { the needs of the local and } \\
\text { international market }\end{array}$ & & & & & \\
\hline 32 & $\begin{array}{l}\text { The University seeks to } \\
\text { develop educational process } \\
\text { continuously }\end{array}$ & & & & & \\
\hline
\end{tabular}

